\title{
Coping Strategy on Recidivism Prisoners in Penitentiary Class II B of Garut, West Jawa Indonesia
}

\author{
Yulian Mutiara Agustin ${ }^{1}$, Nur Octavia Hidayati ${ }^{2}$, Iwan Shalahuddin ${ }^{3 *}$ \\ 1,2,3*) Fakultas Keperawatan Universitas Padjadjaran
}

\begin{tabular}{l} 
ARTICLE INFO \\
\hline Article history: \\
Received February 15, 2019 \\
Revised March 25, 2019 \\
Accepted March 29, 2019 \\
\hline
\end{tabular}

Keyword:

Penitentiary

Prisoners

Coping Strategy

Correctional Facilitiy

Criminals

*) corresponding author

Nursing Faculty Lecturer at Padjadjaran University, Bandung

Street of Bandung-Sumedang KM 21

Jatinangor Jawa Barat Indonesia.

Email: shalahuddin@unpad.ac.id

DOI:https://doi.org/10.30604/jika.v4i1.173

\begin{abstract}
A B S T R A C T
A coping strategy is an activity when an individual tries to manage or maintain a distance between existing demands and the resources of his empowers in dealing with stress, recidivism is a crime committed by individuals repeatedly. Recidivism can be avoided if individuals have adequate coping strategy and high self control. This study is aimed to recognize the description of coping strategy for recidivism criminals at a correctional facility in Garut. The research method used was descriptive quantitative, the total sample of this study was 84 respondents gained by total sampling technique. Data collection was obtained through questionnaires from the use of A-COPE coping strategy, measurement, this study used frequency distribution analysis, the result shows that most recidivism criminals as much as $60.7 \%$ used problem-focused coping strategy and some respondents as much as 33 people or $39.3 \%$ used emotion-focused coping strategy, the efforts used are confrontational as much as $59.3 \%$. It can be concluded that criminals were mostly more likely to use problem-focused coping strategy as much as $60.7 \%$, it is advised that correctional facility class II B Garut provide individual counseling services for recidivism criminals in prison.
\end{abstract}

This is an open access article under the CC-BY-SA license.

\section{INTRODUCTION}

Crimes in this era of globalization are increasing and increasing, and it is not a strange thing anymore, it happens because it is driven by the progress of a place or region such as in big cities, so that it can be an opportunity to increase the number of prisoners who enter and are imprisoned (Waldani, Saam, \& Umari, 2017).

Prisoners are convicts who have gone through criminal acts and lost their independence for a certain period of time and are placed in a prison institution according to 
the Law of the Republic of Indonesia Number 12 of 1995.

Prisoners in Indonesia are currently increasing, in 2018 the number of Prisoners in West Java is 16,811 people, while in the Garut Regency Correctional Institution the number of Prisoners is 542 people with over capacity by $4 \%$ in 2017, and in 2018 there are 634 people with over capacity $20 \%$. Because of the over capacity, the guidance and services in the LAPAS are hampered. This causes officers to be unable to foster inmates properly because the number of officers is not proportional to the number of prisoners, this also causes prisoners to become recidivism, recidivism arises due to the individual's inability to handle stress.

Based on that, it is very vulnerable for prisoners to experience pressure in prisons, related services and obstructed coaching, making prisoners have difficulty living in class II B Garut correctional institutions, it is also supported by several studies, according to the results of research conducted by Ilmi (2017) get the results of normal stress levels $37.5 \%$, mild stress as much as $18.8 \%$, moderate stress $25.5 \%$, stress severe $25.5 \%$, very heavy stress $6.3 \%$, related to that prisoners in prisons class II B Garut also experiences stress signs and symptoms.

Stress if left untreated can cause quite dangerous risks, according to Ghani, Ahmad, \& Ibrahim (2014) found that stress and depression can risk self-harm and suicide in prison. The stress experienced by a person can produce a physical and psychological response, said Waldani et al. (2017) that the stress experienced by inmates is the body's reaction both physically, psychologically, for example shortness of breath, cold sweats, heart palpitations, feeling frustrated, tense, aggression and anger.

Information obtained from the LAPAS officer stated that there were raging inmates and ransacking the bathroom by $13 \%$, seen crying $35 \%$, daydreaming $44 \%$ and trying to run away $5 \%$, there was a fight between inmates to cause injuries by $3 \%$.

Related to this, there is a need for appropriate coping strategies so that the stress experienced by prisoners does not worsen or increase, when inmates are unable to manage the pressure they face, then they are wrong in taking action, related to inappropriate coping strategies used, then it is which makes inmates become recidivists.

Copying strategies that can be carried out are of two types, including the first problemfocused coping (Problem Focused Coping) where a person tends to change the problem or his environment by reducing demand and extending sources to deal with stress. These methods can be aggressive and high anger (Confrontative Coping), help with other people's information (Seeking Social Support), and by careful, analytical, gradual (Planful Problem Solving)

Second, emotion-focused coping (Emotion Focused Coping) where a person better regulates his emotional response to stressful situations with cognitive and behavioral approaches. The second way can be shaped to regulate the feeling of a pressing situation (Self Control), create a positive thing that considers a joke (Distancing), look for positive meaning with a religious approach (Positive Reapprasial), consider the problem is the responsibility and tend to accept well (Accepting Responsibility) and tend to avoid problems that occur by diverting to other things (Escape/Avoidance) (Nasir and Muhith, 2011).

According to Wang, et al. (2014) found that the crime committed by recidivism was due to the failure of coping strategies and coping inadequacies so that it became a trigger for recurring crimes, which was also supported by the research of Yusuf \& Patrisia (2017) who found recidivism self control scores in the Suka Miskin class 1 of prison in Bandung, that their self control scores were low. 
According to Baranyi's research, et al (2018) found that the prevalence of PTSD (post traumatic stress disorder) in 1980-2017 in prisons from 20 countries around the world was relatively high, stress if not handled could cause quite dangerous risks, according to Ghani et al. (2014), it is necessary to have the right coping strategies so that the stress experienced by prisoners does not worsen or increase (Neneng Nurul Sopiah \& Simanjuntak, 2017)

According to research Ayuningtyas (2016) said that most or as many as 74 inmates in class II A Ambarawa correctional institution use coping strategies that focus on emotions.

Sayekti Ruffaida's research (2019) found that male adolescents in class I detention centers in Bandung used coping strategies that focused on emotions, because the resources there were limited, and more supportive of coping strategies that focused on emotions, because the facilities available such as prayer rooms, channeling skills, sports, watching television, and others, so that it is not possible for them to solve or solve problems faced.

Preliminary study, researchers interviewed five prisoners, three inmates with recidivism categories, two people with non-recidivism categories of the five inmates. It was concluded that what they did when they found difficulties was crying and angry, some said that they were closer to God when he felt very stressed by attending a recitation in the prison in Garut Correctional Facilitiy.

The results of the interview showed that five inmates were using emotion focused coping and there were also those who focused on the problem, therefore the researcher wanted to know the coping used by recidivism inmates in the class II B correctional facility in Garut to deal with stress.

\section{METHOD}

The method of this research was carried out using quantitative descriptive research. This study aims to provide an overview describing coping strategies for recidivism inmates in class II B correctional facilities in Garut. The population of this study was all recidivism inmates at the class II B correctional institution in Garut.

Sampling using probability sampling techniques with a total sampling approach that is equal to 84 respondents. Data collection techniques were carried out by using the A-COPE questionnaire made by Mc Cubbin, HI, \& Sussman, MB (2014) which had been modified by the Apriliant who had previously conducted validity and reliability tests to measure coping strategy indicators used by recidivism prisoners, both problem-focused coping (Problem Focused Coping / PFC) or emotion-focused (Emotion Focused Coping / EFC) and those using both coping mixtures.

Data are grouped into two categories, namely coping strategies that focus on problems and coping strategies that focus on emotions, the data are analyzed using descriptive statistics.

Data collection was conducted in June until July 2018. This study used a quantitative descriptive method with a total sampling sampling technique. Data was collected by distributing questionnaires to 84 respondents. The results of the study are presented in the form of frequency distributions and prevention behavior results divided into two categories, namely coping strategies that focus on problems and coping strategies that focus on emotions.

\section{RESULTS AND DISCUSSION}

This study aims to describe the coping strategies used by recidivism inmates in class II B correctional facilities in Garut. 
Table 1.

Distribution of Frequency of Characteristics of Respondents by Age, Education, Length of stay in prison

\begin{tabular}{|c|c|c|}
\hline Characteristics Respondents & Frequency & Percentage $(\%)$ \\
\hline \multicolumn{3}{|l|}{ Age } \\
\hline $18-25$ years old & 10 & 11,9 \\
\hline $26-45$ years old & 68 & 81,0 \\
\hline 46-65 years old & 6 & 7,1 \\
\hline \multicolumn{3}{|l|}{ Education } \\
\hline $\mathrm{SD}$ & 37 & 32,1 \\
\hline SMP & 13 & 15,5 \\
\hline SMA & 44 & 52,4 \\
\hline \multicolumn{3}{|l|}{ Length of stay in prison } \\
\hline $1-2$ year & 51 & 61,9 \\
\hline 3-4 year & 29 & 33,3 \\
\hline 5-6 year & 2 & 2,4 \\
\hline $7-8$ year & 2 & 2,4 \\
\hline Total & 84 & 100 \\
\hline
\end{tabular}

Based on table 1 shows that most of the respondents aged $26-45$ years or $81 \%$, the most recent education respondents were high school (upper secondary school) as much as
$52.4 \%$, based on length of stay in prison showed most of the respondents had undergone.

Table 2.

Respondent Frequency Distribution Based on Coping Strategy Used

\begin{tabular}{ccc}
\hline \multicolumn{1}{c}{ Coping Strategy } & Frequency & Percentage $(\boldsymbol{\%})$ \\
\hline $\begin{array}{l}\text { PFC (problem focused coping) coping strategies that focus on } \\
\text { problems }\end{array}$ & 51 & 60,7 \\
\hline $\begin{array}{l}\text { EFC (emotion focused coping) coping strategies that focus on } \\
\text { emotion }\end{array}$ & 33 & 39,3 \\
\hline Total & 84 & 100 \\
\hline
\end{tabular}

Based on table 2 shows that most of the on the problem (problem focused coping) as respondents use coping strategies that focus much as $60.7 \%$.

Table 3.

Respondent Frequency Distribution Based on Koping Indicators that are Used.

\begin{tabular}{lcc}
\hline \multicolumn{1}{c}{ Indicator } & Frequency & Percentage (\%) \\
\hline Confrontative & & \\
Use & 50 & 59,5 \\
Do not use & 34 & 40,5 \\
\hline Seeking social support & 38 & 45,2 \\
Use & 46 & 54,8 \\
Do not use & 44 & 52,4 \\
\hline Painful problem solving & 40 & 47,6 \\
Use & $\mathbf{8 4}$ & $\mathbf{1 0 0}$ \\
Do not use & Total & \\
\hline
\end{tabular}

Source: Using the A-SCOPE Measurement Tool 
Based on table 3, it can be seen that in coping strategies that have focused on the problem, the most used by recidivists is a confrontative effort of 50 people $(59.5 \%)$.

Based on the results of the study found that most of the respondents used coping strategies that focused on the problem or by $60.7 \%$.

This is in line with the results of a study funded by Fayemi (2016) on female prisoners in Nigeria. The results of studies that are not in line with the results of this study are Sayekti Ruffaida's research (2019) found that prisoners in class I Bandung detention center, using coping strategies that focus on emotion.

Research conducted by Dean Kesuma (2016) is also not in line with this study, which found that the stress faced by juvenile inmates was related to a lack of family support, they used coping strategies that focused on emotions such as watching tv, making crafts, according to them useful because they are able to forget the punishment that is being lived.

The results of the study of Agbakwuru \& Awujo (2016) are also not in line with this study which found prisoners in Nigeria to use coping-focused coping strategies to overcome various challenges as well as various physical violence that occurred during detention.

The characteristics of respondents based on the age of the most at the age of 26-45 years as many as 68 people or $81 \%$, this is in line with the study of Fayemi (2016) who found that the most age is the age of 26-30 years as many as 8 people or $25 \%$ the second result of this study found respondents who mostly used coping strategies focused on problems. According to some (2014) that increasing age, the more mature individuals in solving problems.

The indicators used in the results of this study on recidivism are confrontational at $59.5 \%$, this effort is an effort used to change a problem in an aggressive, risk-taking, and with high anger. The results of this study are different from Santi's study (2015) which found that in female prisoners, the efforts used were seeking social support.

The results of this study show that recidivism inmates in the class II B correctional institution Garut are more likely to use coping strategies that focus on problems, and the most widely used efforts are confrontational, these efforts are good if used outside the prison, but if these efforts are used when convicts are recidivists being in the prison, this can pose a risk of violation, because in prison there are various kinds of rules, and all these must be obeyed by all prisoners, not least by recidivism, if inmates endeavor to use confrontational efforts, for example the occurrence of fights between fellow inmates or the occurrence of physical violence committed by other inmates against him, if by confrontational efforts or by aggressive means and taking risks, it can cause fights between prisoners, and that is a violation in prison.

\section{CONCLUSIONS AND RECOMMENDATION}

Based on the results of the research and discussion, it can be concluded that the majority of respondents used coping strategies that focused on the problem of $60.7 \%$ or 51 inmates and almost half of the respondents used emotional-focused coping strategies of 33 people or $39.3 \%$.

Efforts used by recidivists are confrontational as much as $59.5 \%$. To be able to pay more attention to the psychological state of the prisoners, LAPAS created a program that supports appropriate coping strategies for prisoners, so that inmates do not feel depressed and when they leave prison prisoners do not return to recidivism prisoners, and provide counseling services to psychologists for inmates.

Nurses who are in correctional institutions must be able to direct prisoners to use appropriate coping strategies so that nurses 
must approach and counsel regularly to prisoners in prisons.

\section{REFERENCES}

Agbakwuru, C., \& Awujo, G. C. (2016). Strategies for Coping with the Challenges of Incarceration among Nigerian Prison Inmates. Journal of Education and Practice, 7(23), 153157. Retrieved from https://files.eric.ed.gov/fulltext/EJ1112 896.pdf

Ayuningtyas, W. (2016). Perbedaan Psychological Well-Being Ditinjau Dari Strategi Coping Pada Narapidana Lapas. Retrieved from http://repository.uksw.edu/bitstream/12 3456789/10194/2/T1_802012114_Full text.pdf

Baranyi, G., Cassidy, M., Fazel, S., Priebe, S., \& Mundt, A. P. (2018). Prevalence of Posttraumatic Stress Disorder in Prisoners. Epidemiologic Reviews, 40(1), 134-145. https://doi.org/10.1093/epirev/mxx015

Diyan Kesuma, D. (2016). Stress dan Strategi Coping pada Anak Pidana (Studi Kasus di Lembaga Permasyarakatan Kelas II A Samarinda). Psikoborneo, 4(3), 483-493. Retrieved from http://ejournal.psikologi.fisip-

unmul.ac.id/site/wpcontent/uploads/2016/10/Jurnal\%20DE CKY\%20DIYAN\%20KESUMA\%20\%20ONLINE\%20(10-20-16-04-2456).pdf

Fayemi, J. A. (2016). A Qualitative Exploration of the Coping Strategies of Female Offenders in Nigerian Prisons. International Journal of Criminology and Sociological Theory. 9(1), 1-14. Retrieved from https://ijcst.journals.yorku.ca/index.ph p/ijcst/article/viewFile/40254/36353
Ghani, M. Z., Ahmad, A. C., \& Ibrahim, S. (2014). Stress among Special Education Teachers in Malaysia. Procedia - Social and Behavioral Sciences, 114, 4-13. https://doi.org/10.1016/j.sbspro.2013.1 2.648

Ilmi, Z. M. (2017). Pengaruh Relaksasi Otot Progresif Terhadap Tingkat Stres Narapidana Wanita di Lapas Kelas II A Jember. E-Journal Pustaka Kesehatan, 5(3), 497-504. Retrieved from

https://jurnal.unej.ac.id/index.php/JPK/ article/view/6141/4550

Mc Cubbin, H. I., \& Sussman, M. B. (2014). Social stress and the family: Advances and developments in family stress therapy and research. London: Routledge.

Nasir, A., \& Muhith, A. (2011). Dasar-dasar keperawatan jiwa: pengantar dan teori. Jakarta: Salemba Medika.

Neneng Nurul Sopiah, D. K., \& Simanjuntak, M. (2017). Kerentanan, strategi koping, dan penyesuaian anak di lembaga pembinaan khusus anak (lpka), 10(3), 192-203. https://doi.org/10.24156/jikk.2017.10.3 .192

Santi, A. A. (2015). Stres dan strategi coping pada narapidana wanita di Lembaga Pemasyarakatan Kelas IIA Wanita Semarang (Skripsi). Retrieved from http://repository.uksw.edu/bitstream/12 3456789/9443/2/T1_802011029_Full text.pdf

Sayekti Ruffaida, F. (2019). Strategi Koping pada Remaja Laki-Laki di Rumah Tahanan Kelas I Bandung, Jawa Barat. Jurnal Ilmu Keperawatan (Journal of Nursing Science), 4(1), 64-72. https://doi.org/10.21776/ub.jik.2016.00 4.01.7

Waldani, J., Saam, Z., \& Umari, T. (2017). The Influence of Group Guidance to 
Stress Levels of Women Inmates (Non Drug Cases) at Pekanbaru Children's Correctional Institution, 4 (2), 1-12. Retrieved from https://jom.unri.ac.id/index.php/JOMF KIP/article/view/15955/15488

Wang, X., Hay, C., Todak, N. E., \& Bales, W. (2014). Criminal Propensity, Social Context, and Recidivism: A Multilevel Analysis of Interactive Relationships. Criminal Justice and Behavior, 41(3), 300-317.

https://doi.org/10.1177/009385481350 $\underline{7055}$

Yusuf, U., \& Patrisia, R. (2017). Pengaruh Terapi Kognitif Perilaku Terhadap
Peningkatan Kontrol Diri Pada Residivis. Jurnal Intervensi Psikologi (JIP), 3(2), 245-256. https://doi.org/10.20885/intervensipsik ologi.vol3.iss2.art6

Zuama, H. . S. N. (2014). Hubungan Antara Konsep Diri dengan Strategi Coping pada Mahasiswa Angkatan 2009 Program Studi PG Paud FKIP Universitas Tadulako. Jurnal Kreatif Tadulako, 16(3), 41-51. Retrieved from

https://media.neliti.com/media/publicat ions/123594-ID-hubungan-antarakonsep-diri-dengan-strat.pdf 